\title{
Awareness and readiness of Covid-19 among Bangladeshi residents
}

\author{
Mili Saha ${ }^{1}$, Goutam Saha,"* \\ ${ }^{1}$ Faculty of Arts, Department of English, Jagannath University, Dhaka 1100, Bangladesh \\ ${ }^{2}$ Faculty of Science, Department of Mathematics, University of Dhaka, Dhaka 1000, Bangladesh \\ ${ }^{1}$ Email: milisahadoll@ gmail.com \\ Corresponding author e-mail: *gsahamath@du.ac.bd
}

\begin{abstract}
Bangladesh has adopted some special steps to control the quick spread of the COVID-19 pandemic situation. However, the local residents' knowledge, attitudes, and practices towards the disease have a direct impact on the success of the controlling measures taken by the state. This article explores knowledge $(\mathrm{K})$ about preventions, attitude $(\mathrm{A})$ to the disease, and practices $(\mathrm{P})$ of preventing COVID-19 situation of the young age groups residing in Bangladesh. Quantitative data were collected online using a KAP questionnaire from 932 participants. Results show the population is generally aware of the symptoms, keeping social distance by staying home and are concerned about re-spreading after the lock-down period. However, they are quite unsure about the possible medicines frequently talked about in the media and the necessity of avoiding animal protein. One of the major limitations is, these findings should not be generalized due to the low number of participants compared to the total population in Bangladesh.
\end{abstract}

Keywords: Awareness, Readiness, Covid-19, Bangladesh, Knowledge, Attitude, Practice.

\section{Background}

Bangladesh detected her first COVID-19 infected patients on 8 March, which began with three in number. To the date, it has increased to 2456 on day forty-one, which is the sixth week and indicates the fourth phase of infection (Moral, 2020) called 'Sustained Human-to-Human Transmission' (WHO, 2009). The total number of death has reached 100 including ten deaths and around 300 new infections every day, which indicates the rapid rise period. However, the government has locked-down the highly affected areas and a general leave has been declared to keep all the private and public business and service farms remain closed. In spite of all the steps taken by the state, COVID-19 is still an infectious health issue and should be prevented perceptively by the individuals. This is more about a personal preclusion than authority care to reduce the infection. Knowledge, attitudes, and practices towards infectious diseases involve some panic emotions among the population, which might promote complications in preventing the disease and spread (Zhong et al. 2020). Hence, understanding the public awareness level and readiness to manage the outbreak of COVID-19 in Bangladesh is crucial at the rapid rise period.

KAP refers to Knowledge (what is known), Attitude (what is thought), and Practices (what is done). A KAP survey of any community in relation to a particular topic serves as an educational diagnosis of that population through examining what people know, what they believe, and how they behave (Good, 1994; Ribeaux \& Poppleton, 1978; Tannahill, 2008). KAP is a very common tool used in health-seeking research (WHO, 2008). This KAP study explores what Bangladeshi residents know about Covid-19 symptoms and prevention, how they view the socio-cultural effects of the disease, and what practices they use to prevent the infection. Understanding the KAP of the local residents might enable the government and other authorities to introduce and implement "a more efficient process of awareness creation programs" which will more appropriately address the interventional needs of the community (Kaliyaperumal, 2004). 
We performed this study to get and inform a better understanding of residents, which might identify any knowledge gaps, attitudes, and factors influencing beliefs and actions. Since no studies report about the community's KAP of Covid-19 and the information essential to decide steps and select the program priorities, this research could be significantly useful for the local administration to reintegrate more impactful policies and successful measures to control infections and improve protection after the lock-down period. Bangladesh is almost at the peak of infection and the fight against Coronavirus disease is continuing here. To ensure the last victory, "people's adherence to the control measures are essential, which is largely affected by their knowledge, attitudes, and practices (KAP)" (Ajilore et al., 2017, Tachfouti et al., 2012).

People are, in general, willing to maintain social distance and quarantine which can slow down the infection, although they have high anxiety about possible infection, which can be reduced through increasing awareness and addressing mental health issues (Roy et al., 2020). Most of the participants are young at the age of this study and 'younger individuals are more likely to be asymptomatic when infected and could be unaware they are putting others at risk' (Dong et al. 2020). On the other hand, chances of infection and the severity of illness are much direr with aged people (Zhou et al., 2020). However, hasty lifting of lock-down can promote a secondary peak while lifting lock-down gradually can flatten it (Prem et al. 2020). Studying individual awareness can motivate people to practice the preventive measures discussed in the research and alert them in turn, in addition to knowing about the practices of a large population to avoid mass contamination.

\section{Research design}

This research has been executed in Bangladesh and an online survey was prepared using one of the popular Google tools called Google Forms. The link to the questionnaire was saved for future use. We ensured the participants that the given personal information and opinion will be kept confidential. The research questions include three aspects of the pandemic spreading rapidly in the country:

a. Information about the symptoms and cure.

b. Insights about social attitudes and re-spreading of the virus.

c. Actions performed to practice prevention.

\section{Participants:}

Most of these participants have a minimum educational background which is a Higher Secondary School Certificate level and use any one of the below mentioned online platforms. Our goal was to reach a bigger audience in order to elicit maximum responses from the participants.

\section{Tools:}

The questionnaire consists of two sections including demographics and KAP inquires. Social demographic variables, such as age, gender, and place of residence (Dhaka vs. other districts in Bangladesh) were sought. Following the clinical and community management of COVID-19 guidelines by the Institute of Epidemiology, Disease Control and Research (IEDCR), Bangladesh, we prepared a COVID-19 awareness questionnaire including twelve questions (Table 1). Five of the questions are regarding clinical arrangements (K1-K4), three are regarding the spreading medium (K5-K7), and five of them involve prevention and control (K8-K12) of the virus. The questions are answered on a yes/no basis with an extra 'not sure' option. We assigned 3 points for the first option, 2 points for the second option, and 1 for every third option. The total knowledge score ranged from 1 to 32 , which denotes better knowledge with higher scores. The Cronbach's alpha coefficient was 0.79 indicating acceptable internal consistency of the KAP questionnaire. 


\section{Data Collection:}

We provided the participants with the link using different online platforms including Facebook, Messenger, Google talk, email, and requested them to share the link with their friends and relatives on any social media so that they can respond as well. Data collection began at 10 a.m. on 17 April 2020 and ended at 10 a.m. on 20 April 2020. In addition, we requested participants' demographic information comprising gender identity, marital status, and place of residence. 565 male and 367 females in a total of 932 participants responded to the online survey. Among all, 574 participants belong to the age group ranging from 18 to 25 years, 349 of them belong to the age group ranging from 26 to 49 years, and only 9 participants are at the age group of 50 years and above. Also, 679 participants identify themselves as single and the remaining 253 of them are married. Besides, 514 respondents live in the Dhaka division which is the most infected region in the country and other 418 participants live outside the Dhaka division.

\section{Data Analysis:}

Later the data have been examined and categorized by the percentage of the agreement, disagreement, and personal preferences in each question. Also, data were analyzed using statistical software SPSS with 5\% significance level and two sided T-test were considered for statistical analysis. The conclusion evaluates and discusses these referring to the standard choices needed to prevent the fatal disease.

\section{Results and discussion}

\section{a. Knowledge}

In response to the first question, $78.76 \%$ respondents report of the complete awareness about the varied symptoms of COVID-19 and common flu while $14.80 \%$ are still unsure and $6.44 \%$ are not aware of the differences as shown in Fig. 1, which can be either fatal or stressful for them.

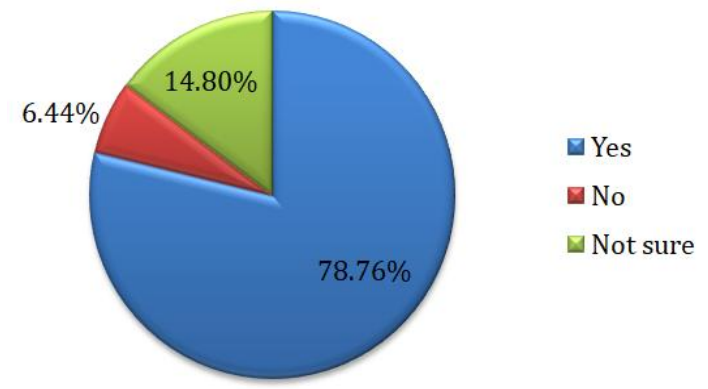

Figure 1: Symptoms of COVID-19 and common flu

Table 1

\begin{tabular}{lccl}
\hline Respondent Types & Yes (\%) & No (\%) & Not sure (\%) \\
\hline \multicolumn{5}{c}{ Gender } \\
\hline Male & 75.22 & 9.03 & 15.75 \\
\hline Female & 84.2 & 2.45 & 13.35 \\
\hline $18-25$ & Age groups \\
\hline $26-49$ & 76.48 & 14.14 & 9.38 \\
\hline 50 and over & 81.95 & 14.05 & 4.0 \\
\hline \multicolumn{5}{c}{100} & 0 \\
\hline Dhaka division & Place of residence \\
\hline Outside Dhaka division & 82.30 & 5.05 & 12.65 \\
\hline
\end{tabular}


Females, old age groups (50 years and above), and the population living in greater Dhaka are more aware of the differences between the symptoms of COVID-19 and other common flu than the male, younger, and the population living outside Dhaka who are most confused about the COVID-19 symptoms too.

Overall, gender has no significant correlation with the respondents' knowledge about the COVID-19 symptoms and infection $(\mathrm{p}=0.5157)$ although the perceptions about the differences between flu symptoms and COVID-19 vary along with gender $(p=0.02)$. Neither the place of residence is, overall, positively correlated to the participant's knowledge $(p=0.84)$, nor the perceptions about the symptoms are impacted by it. However, age shows a considerable influence on the respondents' general knowledge about the disease $(\mathrm{p}<0.001)$ with no major impact on the concepts of symptoms.

Also, Fig. 2 reveals that the majority of people (59.76\%) are unsure about any proposed or available medicines that can be effective to treat the infected persons. $24.36 \%$ of them absolutely discard the idea of reliable medicine while $15.88 \%$ believe if they are infected, these medicines can help. This confirms the other results demonstrating a particular number of people perceive the severity through media focus, which might be wrong in reality.

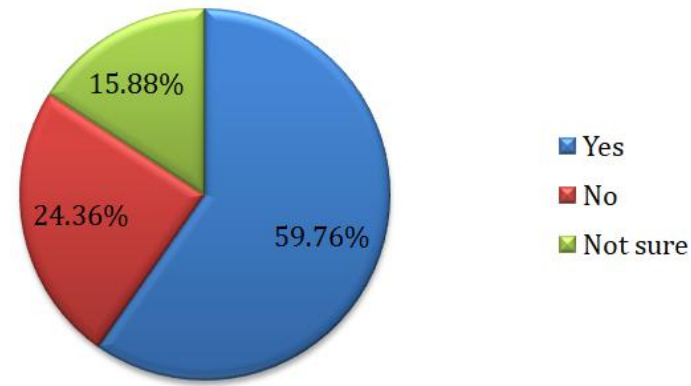

Figure 2: Proposed medicines for COVID-19

Table 2

\begin{tabular}{llll}
\hline Respondent Types & Yes (\%) & No (\%) & Not sure (\%) \\
\hline \multicolumn{4}{c}{ Gender } \\
\hline Male & 19.47 & 24.25 & 56.28 \\
\hline Female & 10.35 & 24.52 & 65.12 \\
\hline \multicolumn{4}{c}{ Age groups } \\
\hline $26-25$ & 16.55 & 22.82 & 60.63 \\
\hline 50 and over & 15.19 & 27.22 & 57.59 \\
\hline \multicolumn{4}{c}{11.11} \\
\hline Dhaka division & 0 & 88.89 \\
\hline Outside Dhaka division & 18.42 & 24.90 & 61.28 \\
\hline
\end{tabular}

However, the knowledge about the proposed medicines differ according to gender $(\mathrm{p}<0.001)$, but age $(\mathrm{p}=0.10)$ and place of residents $(\mathrm{p}=0.11)$ do not influence such awareness. More males, young age groups (18-25), and people from outside Dhaka believe in the medicines presented in media than the female, older and Dhaka resident participants while the most hesitant group is the old aged population.

Fig. 3 shows that a great majority of the respondents (77.68\%) assure us by keeping 1.5 meters distance apart from other people while $8.91 \%$ of them keep less distance and rest $13.41 \%$ are unsure, which defines the careless movement in the community. 


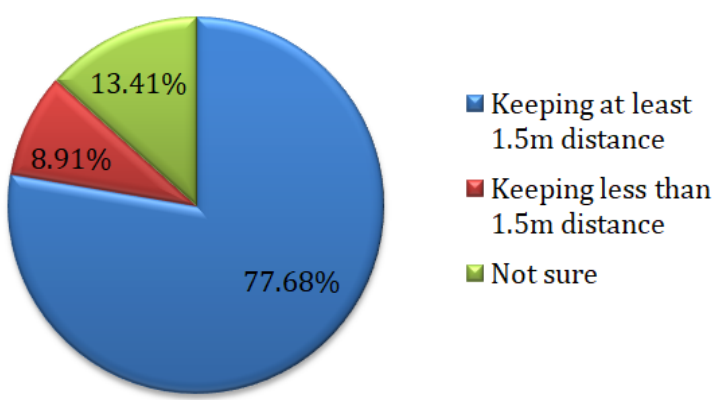

Figure 3: Social distancing

Table 3

\begin{tabular}{|c|c|c|c|}
\hline Respondent Types & $\begin{array}{l}\text { Keeping at least } \\
1.5 \mathrm{~m} \text { distance }(\%)\end{array}$ & $\begin{array}{l}\text { Keeping less than } \\
1.5 \mathrm{~m} \text { distance }(\%)\end{array}$ & Not sure $(\%)$ \\
\hline \multicolumn{4}{|c|}{ Gender } \\
\hline Male & 74.87 & 10.27 & 14.87 \\
\hline Female & 82.02 & 6.81 & 11.17 \\
\hline \multicolumn{4}{|c|}{ Age groups } \\
\hline $18-25$ & 77.53 & 8.19 & 14.29 \\
\hline $26-49$ & 77.65 & 10.03 & 12.32 \\
\hline 50 and over & 88.89 & 11.11 & 0 \\
\hline \multicolumn{4}{|c|}{ Place of residence } \\
\hline Dhaka division & 78.99 & 8.56 & 12.45 \\
\hline Outside Dhaka division & 76.08 & 9.33 & 14.59 \\
\hline
\end{tabular}

Both males and females maintain the right social distancing equally and similar pattern $(\mathrm{p}=$ 0.42 ) and the place of residents does not impact this knowledge of distancing while the age has influences on this $(\mathrm{p}=0.01)$. Again female, old, and non-Dhaka residents groups are keeping more social distance than male, young, and Dhaka-residents groups who are most confused about maintaining the infection detachment.

Figure 4 suggests $64.48 \%$ of respondents believe getting closer to infected persons is the most potent source of COVID-19 transmission in Bangladesh while secondary contact through infected person's used items is the next possible risk of contamination. And, $5.48 \%$ of participants are concerned with air transmission, which indicates this group's extreme awareness about the virus's existence in the environment.

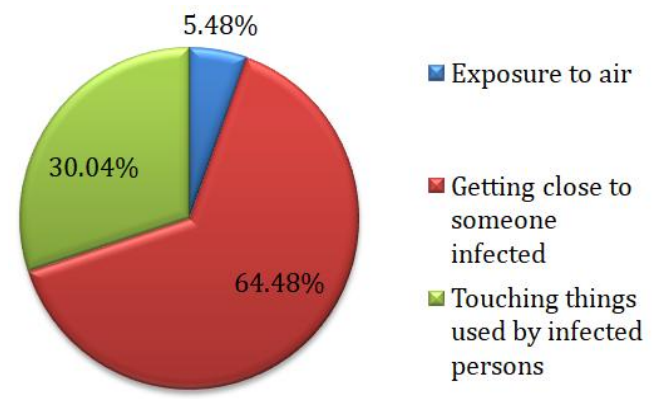

Figure 4: Source of contamination 
Table 4

\begin{tabular}{cccc}
\hline Respondent Types & $\begin{array}{c}\text { Exposure to } \\
\text { air }(\%)\end{array}$ & $\begin{array}{c}\text { Getting close to } \\
\text { someone infected (\%) }\end{array}$ & $\begin{array}{c}\text { Touching things used by } \\
\text { infected persons (\%) }\end{array}$ \\
\hline Gender \\
\hline Male & 4.25 & 66.90 & 28.85 \\
\hline Female & 7.36 & 60.76 & 31.88 \\
\hline $18-25$ & 5.75 & Age groups & 28.75 \\
\hline $26-49$ & 5.16 & 65.51 & 32.09 \\
\hline 50 and over & 0 & 62.75 & 33.33 \\
\hline Dhaka division & 6.23 & 66.67 & 30.16 \\
\hline Outside Dhaka division & 4.55 & 63.62 & 29.90 \\
\hline
\end{tabular}

However, the knowledge about potential sources of contamination differs according to gender ( $\mathrm{p}$ $=0.02)$ and age $(\mathrm{p}<0.001)$ while the place of residence has no considerable impact on it $(\mathrm{p}=$ 0.36). 18-25 and 26-49 age groups have comparable beliefs about the local sources of contamination, although female participants tend to believe more in air transmission and touching things used by infected persons than males. The old age group completely ignores the possibility of air transmission.

Figure 5 shows that the greater majority of the respondents $(42.51 \%)$ prefer to take all preventive measures than testing (54.81\%) if they discover COVID-19 symptoms in them. The worst risk is still $2.67 \%$ of respondents plan to hide about the potential infection from others, which can be detrimental for their surroundings.

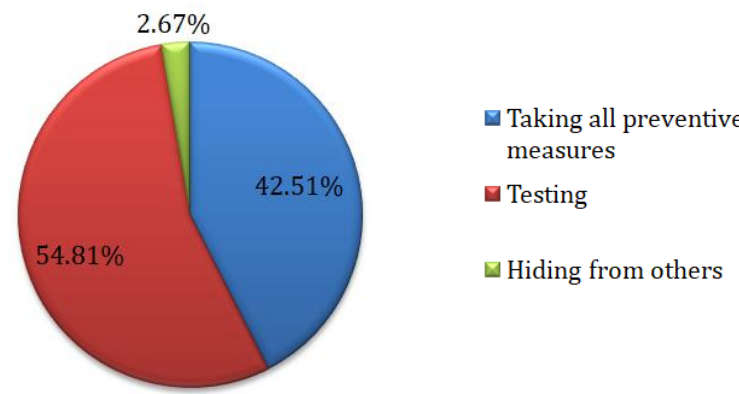

Figure 5: Measures after infection

Table 5

\begin{tabular}{cccc}
\hline Respondent Types & $\begin{array}{c}\text { Taking all preventive } \\
\text { measures }(\%)\end{array}$ & $\begin{array}{c}\text { Testing } \\
(\%)\end{array}$ & $\begin{array}{c}\text { Hiding from } \\
\text { others }(\%)\end{array}$ \\
\hline Gender & & \\
\hline Male & 42.22 & 54.89 & 2.89 \\
\hline Female & 43.10 & 54.88 & 2.02 \\
\hline $18-25$ & Age groups & \\
\hline $26-49$ & 57.97 & 39.34 & 2.69 \\
\hline 50 and over & 47.88 & 49.42 & 2.70 \\
\hline & 66.67 & 33.33 & 0.0 \\
\hline Dhaka division & Place of residence & \\
\hline Outside Dhaka division & 43.98 & 52.58 & 3.44 \\
\hline
\end{tabular}


The measures taken by the males and females do not differ $(p=0.66)$ after being infected, neither place of residence $(\mathrm{p}=0.01)$ has any impact although the participants of different ages take different measures $(\mathrm{p}<0.001)$. Both male and female groups are equally interested in trying the preventive measures, testing, and hiding about it if they are found infected. The old age group is most interested in preventive measures; non-Dhaka residents are aware of testing most; Dhaka-residents are prone to hide most. However, the old age group is not at all interested in hiding.

\section{b. Attitude}

The research participants are generally anxious about the negative social attitudes, negligence, and rudeness showed towards the COVID-19 patients in Bangladesh. Figure 6 shows that $48.06 \%$ of them are frustrated, $40.24 \%$ are afraid and $11.70 \%$ are angry to see such insolence and humiliation including abundance, refusal, and limited access to treatment, avoidance, and rejection from both family and society.

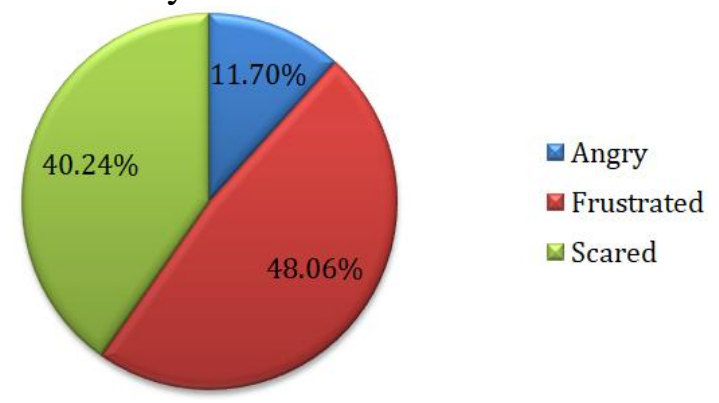

Figure 6: Social negligence to the infected persons

Table 6

\begin{tabular}{cccc}
\hline Respondent Types & $\begin{array}{c}\text { Angry } \\
(\%)\end{array}$ & $\begin{array}{c}\text { Frustrated } \\
(\%)\end{array}$ & $\begin{array}{c}\text { Scared } \\
(\%)\end{array}$ \\
\hline \multicolumn{4}{c}{ Gender } \\
\hline Male & 10.97 & 48.85 & 40.18 \\
\hline Female & 12.81 & 46.87 & 40.33 \\
\hline \multicolumn{4}{c}{ Age groups } \\
\hline $26-49$ & 11.15 & 46.34 & 42.51 \\
\hline 50 and over & 12.32 & 50.43 & 37.25 \\
\hline \multicolumn{4}{c}{ Place of residence } \\
\hline Dhaka division & 13.04 & 48.05 \\
\hline Outside Dhaka division & 10.05 & 48.09 \\
\hline
\end{tabular}

The male and female participants have different attitudes $(\mathrm{p}<0.0001)$ towards the cruelty and negligence shown to the infected persons while the place of residence $(p=0.50)$ has no impact on such attitudes. Also, young and mature participants differ $(p=0.007)$ in their reactions to such behavior.

The groups have similar reactions to the negative social attitudes, rudeness, and negligence shown to the Corona patients in Bangladesh, although the old age group is more angry and frustrated, although least scared with this attitude. 
Figure 7 shows a great majority of the respondents (49.25\%) are concerned that the virus will respread as soon as the lock-down is relaxed. A very minor group (13.84\%) believes the situation will become normal while $36.91 \%$ of them are unsure about the choices.

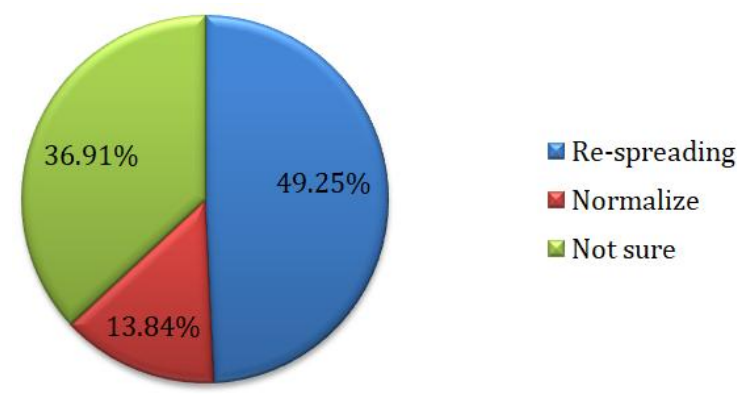

Figure 7: Post-lock-down re-spreading

Table 7

\begin{tabular}{cccc}
\hline Response & $\begin{array}{c}\text { Re-spreading } \\
(\%)\end{array}$ & $\begin{array}{c}\text { Normalize } \\
(\%)\end{array}$ & $\begin{array}{c}\text { Not sure } \\
(\%)\end{array}$ \\
\hline \multicolumn{4}{c}{ Gender } \\
\hline Male & 48.67 & 15.22 & 36.11 \\
\hline Female & 50.14 & 11.72 & 38.15 \\
\hline \multicolumn{4}{c}{ Age groups } \\
\hline $26-49$ & 46.69 & 15.33 & 37.98 \\
\hline 50 and over & 53.87 & 11.75 & 34.38 \\
\hline \multicolumn{5}{c}{33.33} \\
\hline Dhaka division & Place of residence & 0.0 \\
\hline Outside Dhaka division & 50.39 & 14.20 \\
\hline
\end{tabular}

However, none of the variables including gender $(p=0.92)$, place of residence $(p=0.33)$, and age $(p=0.5962)$ make any differences in the participants' beliefs about post-lock-down respreading. Female participants are more anxious about COVID-19 re-spreading after the lockdown is lifted up and are less optimistic about normalizing the situation than the male respondents. Also, the old age group is least concerned about re-spreading, least hopeful about normalizing, and most confused about choosing any of the options.

Disinfecting things and washing hands will be the second priority to the participants $(29.08 \%)$ while keeping a social distance is the highest priority (47.42\%) as shown in Fig. 8, which the World Health Organization emphasizes. Although wearing safety masks and gloves is least preferred after the lock-down period, this is the most common practice at this rapid rise period.

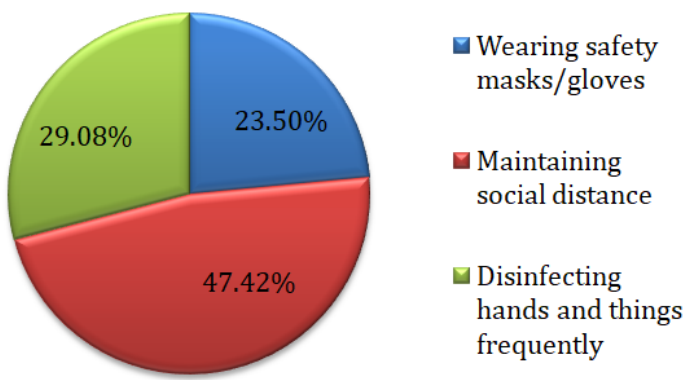

Figure 8: Post-lock-down-safety 
Table 8

\begin{tabular}{cccc}
\hline Respondent Types & $\begin{array}{c}\text { Wearing safety } \\
\text { masks/gloves (\%) }\end{array}$ & $\begin{array}{c}\text { Maintaining social } \\
\text { distance (\%) }\end{array}$ & $\begin{array}{c}\text { Disinfecting hands and } \\
\text { things frequently (\%) }\end{array}$ \\
\hline \multicolumn{4}{c}{ Gender } \\
\hline Male & 26.73 & 49.38 & 23.89 \\
\hline Female & 22.89 & 44.41 & 32.70 \\
\hline \multicolumn{5}{c}{ Age groups } \\
\hline 18-25 & 23.69 & 50.70 & 25.61 \\
\hline 50 and over & 23.21 & 42.12 & 34.67 \\
\hline \multicolumn{5}{c}{22.22} & 44.44 \\
\hline Dhaka division & 23.35 & 43.19 & 33.33 \\
\hline Outside Dhaka Division & 23.68 & 52.63 & 23.68 \\
\hline
\end{tabular}

On the other hand, all of the gender $(\mathrm{p}=0.0095)$, place of residence $(\mathrm{p}=0.03)$, and age $(\mathrm{p}<$ 0.0001) have a considerable impact on the respondents' attitude to the post-lock-down-safety. However, male participants outperform the female group regarding the post-lock-down awareness and the data shows the male group is more likely to wear safety masks and gloves and maintaining social distance while the female group is prone to washing hands and disinfecting things more frequently than the male group. Also, young groups and non-Dhaka residents outperform the counter old aged and Dhaka-resident groups with more awareness about the upcoming risk.

\section{c. Practice}

In spite of being remarkably alert about keeping social distance and not coming in contact with community members, the majority section of the research population $(81.65 \%)$ are relaxed about eating animal protein including eggs, meat or fish while $7.84 \%$ are super conscious about such transmission and have been avoiding eggs and milk as shown in Fig. 9. Also, another group consisting of $10.51 \%$ keep away from meat and fish. Therefore, the majority of people are at great risk in case the local animal transmission begins.

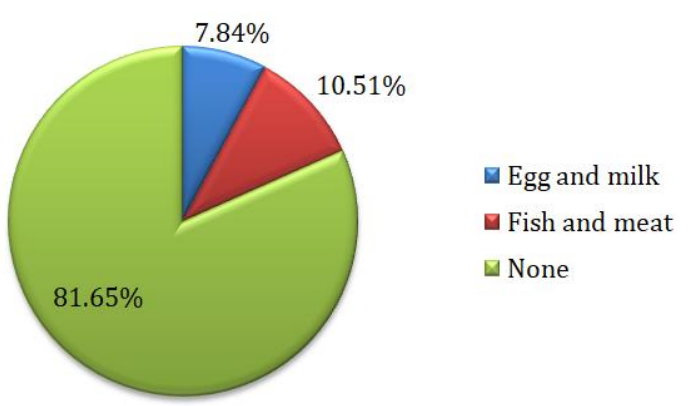

Figure 9: Avoiding animal protein 
Table 9

\begin{tabular}{cccc}
\hline Respondent Types & $\begin{array}{c}\text { Egg and } \\
\text { milk }(\%)\end{array}$ & $\begin{array}{c}\text { Fish and } \\
\text { meat }(\%)\end{array}$ & $\begin{array}{c}\text { None } \\
(\%)\end{array}$ \\
\hline Gender \\
\hline Male & 10.44 & 11.33 & 78.23 \\
\hline Female & 3.81 & 9.26 & 86.92 \\
\hline \multicolumn{4}{c}{ Age groups } \\
\hline $18-25$ & 8.36 \\
\hline 26-49 & 7.16 & 10.80 & 80.84 \\
\hline 50 and over & 0 & 82.52 \\
\hline \multicolumn{5}{c}{ Dhaka division } & Place of residence \\
\hline Outside Dhaka division & 7.37 & 10.32 \\
\hline
\end{tabular}

Gender and ages have a quite significant influence on the participants' practices regarding protecting themselves from COVID-19 infection and treatment of the disease. Fewer females than males can avoid gender $(\mathrm{p}<0.0001)$ and age $(\mathrm{p}=0.006)$ make changes in the participants' attitudes to avoiding animal protein while the place of residence $(\mathrm{p}=0.56)$ makes no impact. Surprisingly old age groups are least concerned about consuming animal proteins to prevent COVID-19 infection, next comes the female groups who avoid less animal protein than the male, and more Dhaka residents avoid animal protein than non-Dhaka residents.

Since $52.36 \%$ of participants are staying home and $34.23 \%$ coming out once a week, it seems those $13.41 \%$ of participants who go for daily shopping are at a greater risk as described in Fig. 10.

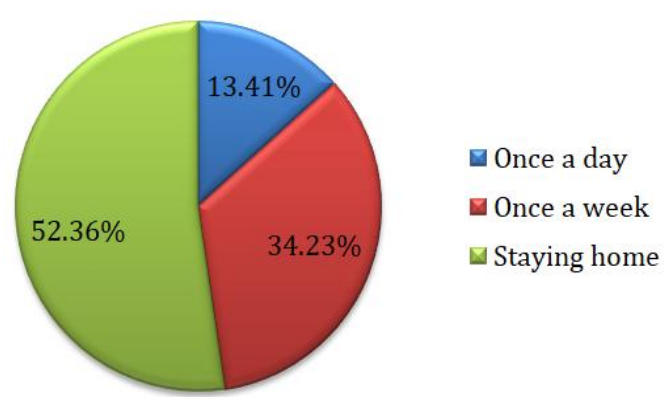

Figure 10: Staying home

Table 10

\begin{tabular}{cccc}
\hline Respondent Types & $\begin{array}{c}\text { Once a day } \\
(\%)\end{array}$ & $\begin{array}{c}\text { Once a week } \\
(\%)\end{array}$ & $\begin{array}{c}\text { Staying home } \\
(\%)\end{array}$ \\
\hline \multicolumn{4}{c}{ Gender } \\
\hline Male & 19.82 & 43.54 & 36.64 \\
\hline Female & 3.54 & 19.89 & 76.57 \\
\hline $18-25$ & Age groups & 57.49 \\
\hline $26-49$ & 11.50 & 31.01 & 43.55 \\
\hline 50 and over & 16.62 & 39.83 & 66.67 \\
\hline \multicolumn{5}{c}{11.11} & 22.22 & 55.45 \\
\hline Dhaka division & Place of residence \\
\hline Outside Dhaka division & 9.34 & 35.21 & 48.57 \\
\hline
\end{tabular}


The male and female participants do not stay home equally $(\mathrm{p}<0.0001)$, neither the Dhaka residents do it equally $(p=0.0006)$ as the non-Dhaka residents. However, age $(p=0.09)$ does not change the home stay of the respondents. As usual, male, mid-young age (26-49 years) and nonDhaka resident groups come out of the home more frequently than female, early-young and old aged as well as the Dhaka-resident groups while female and old age groups are staying home mostly.

Another positive preventative measure that a great majority of the population $(67.17 \%)$ avails is always disinfecting things and taking a bath right after returning home. However, $27.04 \%$ of respondents take this measure less frequently and $5.79 \%$ population do it seldom as shown in Fig. 11, which leaves the risk of infecting the home environment unintentionally and reduces the chance of escaping it.

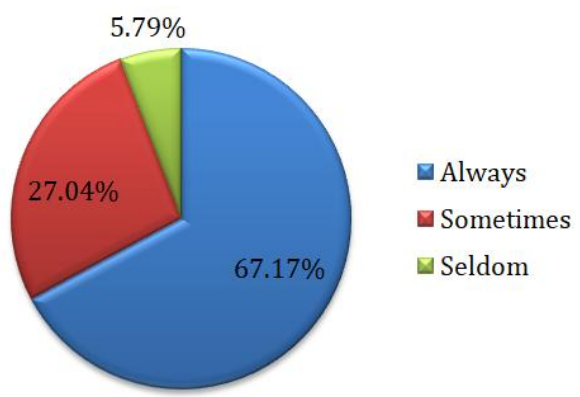

Figure 11: Cleaning and disinfecting

Table 11

\begin{tabular}{cccc}
\hline Respondent Types & $\begin{array}{c}\text { Always } \\
(\%)\end{array}$ & $\begin{array}{c}\text { Sometimes } \\
(\%)\end{array}$ & $\begin{array}{c}\text { Seldom } \\
(\%)\end{array}$ \\
\hline \multicolumn{4}{c}{ Gender } \\
\hline Male & 57.70 & 34.51 & 7.79 \\
\hline Female & 81.74 & 15.53 & 2.72 \\
\hline \multicolumn{4}{c}{ Age groups } \\
\hline $26-49$ & 64.11 & 29.44 & 6.45 \\
\hline 50 and over & 72.49 & 22.64 & 4.87 \\
\hline \multicolumn{5}{c}{ Place of residence } \\
\hline Dhaka division & 74.51 & 0 \\
\hline Outside Dhaka division & 58.13 & 20.82 \\
\hline
\end{tabular}

Regarding taking bath and disinfecting things after coming back from shopping, female, midyoung age, and Dhaka-residents are more careful then the counter groups of male, early-young and old as well as non-Dhaka residents, while the male group is the least and old age group, is the most aware regarding the precaution. Also, male and females have different habits of cleaning and disinfecting ( $\mathrm{p}<0.0001)$; also the populations living in Dhaka and outside Dhaka have different attitudes to this habit. Although the habit does not differ according to age ( $\mathrm{p}=$ 0.07 )

As Fig. 12 shows, majority of the participants (51.06\%) only avoid cold food items and drinks as prevention from the infection, although $44.56 \%$ of them are more cautious about drinking warm water to stop the virus living inside the body and $4.38 \%$ are only taking steam as they thought it can help them to prevent the virus. 


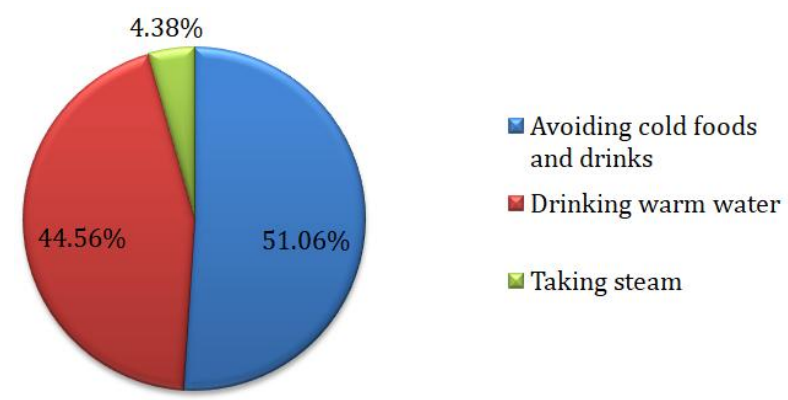

Figure 12: Prevention and Cure

Table 12

\begin{tabular}{|c|c|c|c|}
\hline Respondent Types & $\begin{array}{l}\text { Avoiding cold foods } \\
\text { and drinks }(\%)\end{array}$ & $\begin{array}{l}\text { Drinking warm } \\
\text { water }(\%)\end{array}$ & $\begin{array}{c}\text { Taking steam } \\
(\%)\end{array}$ \\
\hline \multicolumn{4}{|c|}{ Gender } \\
\hline Male & 49 & 45.7 & 5.3 \\
\hline Female & 54.15 & 42.86 & 2.99 \\
\hline \multicolumn{4}{|c|}{ Age groups } \\
\hline $18-25$ & 50.93 & 44.93 & 4.14 \\
\hline $26-49$ & 52.45 & 43.02 & 4.53 \\
\hline 50 and over & 0 & 83.33 & 16.67 \\
\hline \multicolumn{4}{|c|}{ Place of residence } \\
\hline Dhaka division & 48.29 & 47.80 & 3.9 \\
\hline Outside Dhaka division & 54.36 & 40.70 & 4.94 \\
\hline
\end{tabular}

Dhaka and non-Dhaka residents $(p=0.04)$ or young and mature participants $(p=0.02)$ take steps similar to prevent and cure the virus infection while males and females $(p=0.22)$ have different prevention and cure measures. More female, mid-young aged and non-Dhaka resident participants avoid cold food and drinks, more male, old aged and Dhaka-resident participants drink warm water, and more male old aged and non-Dhaka resident respondents take steam to prevent COVID-19 infection than the counter groups. Although female groups are quite aware of avoiding cold foods and drinks, they are least responsive to drinking warm water and taking steam.

The critical part of the findings includes $43.13 \%$ of participants rely on home care than $41.63 \%$ of those who prefer to shift to hospital initially after finding themselves as COVID-19 positive, as shown in Fig. 13. This involves the local people's reliance on the state and physician's policy for treating COVID-19 patients. However, $15.24 \%$ population is indecisive regarding the matter, which could drop them in chaos and delay or cure once they are infected.

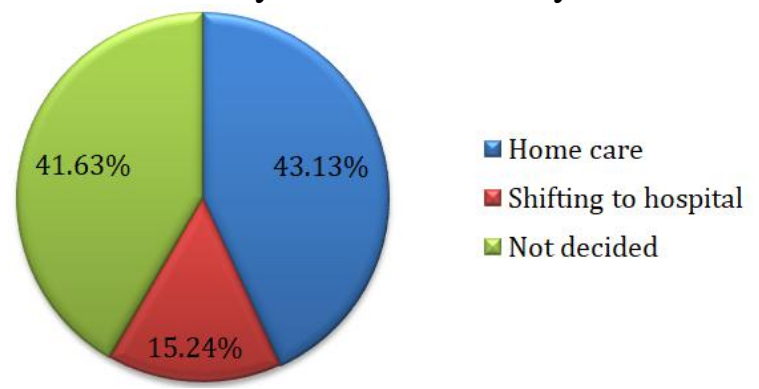

Figure 13: Treatment of infection 
Table 13

\begin{tabular}{cccc}
\hline Respondent Types & $\begin{array}{c}\text { Home care } \\
(\%)\end{array}$ & $\begin{array}{c}\text { Shifting to the } \\
\text { hospital }(\%)\end{array}$ & $\begin{array}{c}\text { Not decided } \\
(\%)\end{array}$ \\
\hline \multicolumn{4}{c}{ Gender } \\
\hline Male & 42.65 & 41.59 & 15.75 \\
\hline Female & 43.87 & 41.69 & 14.44 \\
\hline \multicolumn{5}{c}{ Age groups } \\
\hline $26-49$ & 31.71 & 51.39 & 16.90 \\
\hline 50 and over & 62.18 & 26.07 & 11.75 \\
\hline \multicolumn{5}{c}{33.33} & 22.22 \\
\hline Dhaka division & Place of residence \\
\hline Outside Dhaka division & 46.50 & 37.35 \\
\hline
\end{tabular}

The participants' practices about treating COVID-19 infection vary according to age only ( $\mathrm{p}<$ $0.0001)$, and gender $(\mathrm{p}=0.60)$ or place of residence $(\mathrm{p}=0.24)$ have no impact on the choices between home care or shifting to hospital. The mid young age groups are most prone to stay home if infected while early young age groups prefer shifting to hospital in such cases. And, old age groups are the most indecisive which is a risk too. Also, Dhaka residents rely more on home care and non-Dhaka residents prefer to move to the hospital than staying home. However, gender shows no considerable effects on choosing COVID-19 treatment among the respondents.

Regarding social services, such as raising awareness and informing the community, the $77.86 \%$ participants mainly use the online platform and social media keeping social distance while $15.16 \%$ try to make people aware through practicing the health rules and $6.98 \%$ report about demonstrating the safety tasks to instruct people how to save from infecting as presented in Fig. 14.

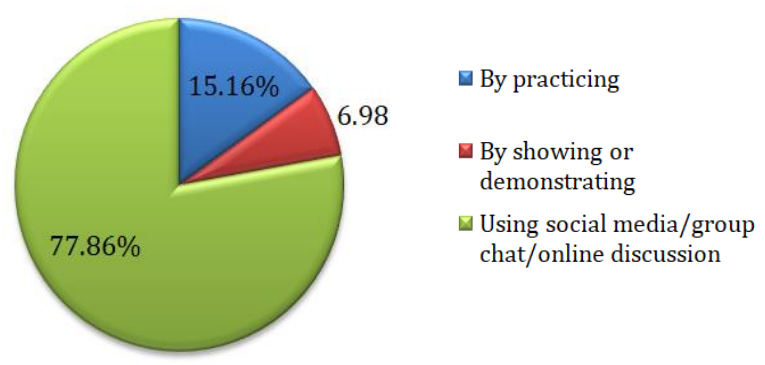

Figure 14: Social awareness work

Table 14

\begin{tabular}{cccc}
\hline Respondent Types & $\begin{array}{c}\text { By practicing } \\
(\%)\end{array}$ & $\begin{array}{c}\text { By showing or } \\
\text { demonstrating (\%) }\end{array}$ & $\begin{array}{c}\text { Using social media/group } \\
\text { chat/online discussion (\%) }\end{array}$ \\
\hline Male & 14.39 & Gender & 78.42 \\
\hline Female & 16.34 & 7.19 & 77.0 \\
\hline $18-25$ & 13.36 & Age groups & 80.49 \\
\hline $26-49$ & 17.94 & 6.15 & 73.53 \\
\hline 50 and over & 25.0 & 8.53 & 75.0 \\
\hline & & Place of residence & 78.57 \\
\hline Dhaka division & 15.08 & 6.35 & 77.0 \\
\hline Outside Dhaka division & 15.25 & 7.75 & \\
\hline
\end{tabular}


Responses regarding raising mass awareness during the pandemic period demonstrate the groups' almost equal share of work using any particular mode of demonstration. However, old age groups are ahead with practicing preventions, early-young age group is best with online work and mid-age groups demonstrate more than other groups. Similarly, only age $(p<0.0001)$ makes differences in the participants' choice of social awareness work; although gender ( $\mathrm{p}=$ $0.88)$ and place of residence $(\mathrm{p}=0.44)$ do not impact the choice at all.

\section{Conclusion}

Findings show Bangladeshi female and old age groups are, on the whole, socially and psychologically connected, although physically distanced and thus, are preventing the risks of infection. However, young age groups are comparatively less aware of the symptoms, social distancing, and outing, which indicates the greater risk involved with the males and population living in the divisions other than Dhaka. Although female participants are more aware regarding many aspects including cleaning, disinfecting, and further outbreak, they are less active in selfcare and avoiding animal meat or fish which might be unsafe. The most significant findings of the study reveal that the old age group is the most alert group, males are the most vulnerable with less care, people living outside Dhaka have less knowledge and preventive measures against the deadly virus, young age group is more optimistic while the female respondent group is prepared most of all participants. Hence, the more awareness and preparation programs should be introduced regarding COVID-19 for the people residing in the remote and underdeveloped areas where mass communication through online technology is limited. The overall findings demonstrate that $16-20 \%$ of respondents comprising mainly the young male groups are at high risk of infection. Also, the analysis of the survey results confirms a correlation between the knowledge and practice of Covid-19 protection in Bangladesh.

\section{Acknowledgment}

We acknowledge Rhun Saha for proofreading the article. 


\section{References}

Ajilore, K., Atakiti, I., \& Onyenankey, K. 2017. College students' knowledge, attitudes and adherence to public service announcements on Ebola in Nigeria: Suggestions for improving future Ebola prevention education programmes. Health Education Journal, vol. 76, p. 648-60.

Cheng, K.K., Lam, H.T., \& Leung, C.C. 2020. Wearing face masks in the community during the COVID19 pandemic: altruism and solidarity. THE LANCET. doi:10.1016/S0140-6736(20)30918-1. Retrieved on 22 April, 2020 from

Link: https://www.thelancet.com/journals/lancet/article/PIIS0140-6736(20)30918-1/fulltext

Dong, Y., Mo, X., Hu, Y., Xin, Q., Jiang, F., Jiang, Z., \& Tong, S. 2020. Epidemiological characteristics of 2143 pediatric patients with 2019 coronavirus disease in China. Pediatrics, article id: e20200702. doi: 10.1542/peds.2020-0702.

Good, B. 1994. Medicine, rationality, and experience: an anthropological perspective. Cambridge: Cambridge University Press.

Kaliyaperumal, K. 2004. Diabetic Retinopathy Project Guideline for Conducting a Knowledge, Attitude and Practice (KAP) Study. Community Ophthalmology, vol. 4, no. 1, p. 7-9.

Link: http://v2020eresource.org/content/files/guideline kap Jan mar04.pdf

Moral, S. 2020. Bangladesh at 4th stage of coronavirus infection. Published in Daily Prothom Alo. Link: https://en.prothomalo.com/bangladesh/bangladesh-at-4th-stage-of-coronavirus-infection

Prem, K., Liu, Y., Russell, T.W., Kucharski, A.J., Eggo, R.M., Davies, N., Jit, M., \& Klepac, P. 2020. The effect of control strategies to reduce social mixing on outcomes of the COVID-19 epidemic in Wuhan, China: a modeling study. Lancet Public Health, doi: 10.1016/S2468-2667, vol. 20, p. 300736.

Ribeaux, P., \& Poppleton, S.E. 1978. Psychology and Work: an introduction. London: Macmillan.

Roy, D., Tripathy, S., Kara, S.K., Sharmaa, N., Vermaa, S.K., \& Kaushalb, V. 2020. Study of knowledge, attitude, anxiety \& perceived mental healthcare need in Indian population during COVID-19 pandemic. Asian Journal of Psychiatry, vol. 51, article id: 102083. doi: 10.1016/j.ajp.2020.102083.

Tannahill, A. 2008. Beyond evidence-to ethics: a decision-making framework for health promotion, public health and health improvement. Health Promot. Int., vol. 23, p. 380-390.

Tachfouti, N., Slama, K., Berraho, M., Nejjari, C. 2012. The impact of knowledge and attitudes on adherence to tuberculosis treatment: a case-control study in a Moroccan region. Pan. Afr. Med. J., vol. 12 , p. 52.

World Health Organization 2008. Advocacy, communication and social mobilization for TB control: a guide to developing knowledge, attitude and practice surveys.

Link: http://whqlibdoc.who.int/publications/2008/9789241596176_eng.pdf.

World Health Organization 2009. Current WHO phase of pandemic alert for Pandemic (H1N1). Link: https://www.who.int/csr/disease/swineflu/phase/en/

Zhou, F., Yu, T., Du, R., Fan, G., Liu, Y., Liu, Z., Xiang, J., Wang, Y., Song, B., Gu, X., Guan, L., Wei, Y., Li, H., Wu, X., Xu, J., Tu, S., Zhang, Y., Chen, H., \& Cao, B. 2020. Clinical course and risk factors for mortality of adult in patients with COVID-19 in Wuhan, China: a retrospective cohort study. Lancet, vol. 395, p. 1054-1062. doi: 10.1016/S0140-6736(20)30566-3. 


\section{Appendix A: Questionnaire}

\section{Your gender:}

A. Male, B. Female

2. Your age group:

A. $18-25$, B. $26-49$, C. $50+$

3. Your place of residence:

A. Dhaka division, B. Outside Dhaka division

\section{Knowledge:}

K1. Are you confirmed about the differences between the symptoms of COVID-19 and the common flu?
A. Yes, B. No, C. Not sure

K2. Do you believe any of the proposed medicines could help to fight against COVID-19?

A. Yes, B. No, C. Not sure

K3. How do you maintain social distance from other people everywhere?

A. Keeping less than $1.5 \mathrm{~m}$ distance, B. Keeping at least $1.5 \mathrm{~m}$ distance, C. Not sure

$\mathrm{K} 4$. What is the most possible way to be infected in Bangladesh?

A. Getting close to someone infected, B. Touching things used by infected persons, C. Exposure to air

K5. What should you do after finding the COVID-19 symptoms in you?

A. Taking all preventive measures, B. Testing, C. hiding from others

\section{Attitude:}

A1. How do you feel to see social attitudes and rudeness towards the COVID-19 positive patients?

A. Frustrated, B. Scared, C. Angry

A2. What risks do you predict after the lockdown is over?

A. Respreading, B. Normalize, C. Not sure

A3. What precautions might prevent you from infection after the lockdown?

A. Wearing safety masks/gloves, B. Maintaining social distance, C. Disinfecting hands and things frequently

\section{Practice:}

P1. Which animal protein are you avoiding to keep safe from COVID-19?

A. Eggs and milk, B. Fish and meat, C. None

P2. How frequently do you go outside for any specific purposes like buying foods/medicines etc?

A. Once a day, B. Once a week, C. Staying home

P3. Do you disinfect your things and take a bath instantly after coming back from outside?

A. Always, B. Sometimes, C. Seldom

P4. What safety measures you avail to prevent infection?

A. Drinking warm water, B. taking steam, C. Avoiding cold foods and drinks

P5. What will you do initially if you are COVID-19 positive?

A. Home care, B. Shifting to hospital, C. Not decided

P6. How do you raise positivity and awareness among others?

A. Using social media/group chat/online discussion, B. By practicing, C. By showing or demonstrating 


\section{Appendix B: Statistical Data Analysis}

\begin{tabular}{|c|c|c|c|c|c|c|c|c|c|c|c|}
\hline \multirow[b]{2}{*}{ No. } & \multicolumn{5}{|c|}{ Male: 565} & \multicolumn{5}{|c|}{ Female: 367} & \multirow[b]{2}{*}{ p value } \\
\hline & A & B & $\mathbf{C}$ & Mean & SD & A & B & $\mathbf{C}$ & Mean & SD & \\
\hline K1 & 425 & 51 & 89 & 2.595 & 0.746 & 309 & 9 & 49 & 2.708 & 0.689 & $0.0201 *$ \\
\hline $\mathrm{K} 2$ & 110 & 137 & 318 & 1.632 & 0.789 & 38 & 90 & 239 & 1.452 & 0.675 & $0.0003^{* * *}$ \\
\hline K3 & 58 & 423 & 84 & 1.954 & 0.500 & 25 & 301 & 41 & 1.956 & 0.422 & 0.9495 \\
\hline K4 & 378 & 163 & 24 & 2.627 & 0.565 & 223 & 117 & 27 & 2.534 & 0.630 & $0.0192 *$ \\
\hline K5 & 239 & 310 & 16 & 2.395 & 0.544 & 158 & 202 & 7 & 2.411 & 0.530 & 0.6578 \\
\hline $\mathbf{A 1}$ & 59 & 64 & 442 & 1.322 & 0.654 & 14 & 34 & 319 & 1.169 & 0.466 & $<0.0001 * * *$ \\
\hline $\mathbf{A 2}$ & 275 & 86 & 204 & 2.126 & 0.913 & 184 & 43 & 140 & 2.120 & 0.933 & 0.9226 \\
\hline A3 & 151 & 279 & 135 & 2.028 & 0.712 & 84 & 163 & 120 & 1.902 & 0.740 & $0.0095 * *$ \\
\hline $\mathbf{P 1}$ & 59 & 64 & 442 & 1.322 & 0.654 & 14 & 34 & 319 & 1.169 & 0.466 & $<0.0001 * * *$ \\
\hline $\mathbf{P 2}$ & 112 & 246 & 207 & 1.832 & 0.733 & 13 & 73 & 281 & 1.270 & 0.518 & $<0.0001 * * *$ \\
\hline $\mathbf{P 3}$ & 326 & 195 & 44 & 2.499 & 0.638 & 300 & 57 & 10 & 2.790 & 0.470 & $<0.0001 * * *$ \\
\hline P4 & 258 & 30 & 277 & 1.966 & 0.973 & 157 & 11 & 199 & 1.886 & 0.980 & 0.2217 \\
\hline P5 & 241 & 235 & 89 & 2.269 & 0.716 & 161 & 153 & 53 & 2.294 & 0.706 & 0.6006 \\
\hline P6 & 443 & 81 & 41 & 2.712 & 0.592 & 283 & 60 & 24 & 2.706 & 0.583 & 0.8792 \\
\hline
\end{tabular}

\begin{tabular}{c|c|c|c|c|c|c|c|c|c|c|c}
\hline & \multicolumn{7}{|c|}{ Dhaka Division: $\mathbf{5 1 4}$} & \multicolumn{3}{c}{ Outside Dhaka Division: 418 } & \\
\hline No. & A & B & C & Mean & SD & A & B & C & Mean & SD & p value \\
\hline K1 & 423 & 26 & 65 & 2.696 & 0.682 & 311 & 34 & 73 & 2.569 & 0.772 & $0.0078^{* *}$ \\
\hline K2 & 71 & 128 & 315 & 1.525 & 0.726 & 77 & 99 & 242 & 1.605 & 0.780 & 0.106 \\
\hline K3 & 44 & 406 & 64 & 1.961 & 0.457 & 39 & 318 & 61 & 1.947 & 0.487 & 0.6517 \\
\hline K4 & 327 & 155 & 32 & 2.574 & 0.608 & 274 & 125 & 19 & 2.610 & 0.574 & 0.3569 \\
\hline K5 & 226 & 270 & 18 & 2.405 & 0.558 & 170 & 240 & 8 & 2.388 & 0.526 & 0.6352 \\
\hline A1 & 247 & 200 & 67 & 2.350 & 0.699 & 201 & 175 & 42 & 2.380 & 0.662 & 0.5048 \\
\hline A2 & 259 & 73 & 182 & 2.150 & 0.915 & 200 & 56 & 162 & 2.091 & 0.927 & 0.3307 \\
\hline A3 & 120 & 222 & 172 & 1.899 & 0.748 & 99 & 220 & 99 & 2.000 & 0.689 & $0.034 *$ \\
\hline P1 & 43 & 54 & 417 & 1.272 & 0.605 & 30 & 44 & 344 & 1.249 & 0.576 & 0.5555 \\
\hline P2 & 48 & 181 & 285 & 1.539 & 0.660 & 77 & 138 & 203 & 1.699 & 0.762 & $0.0006^{* * *}$ \\
\hline P3 & 383 & 107 & 24 & 2.698 & 0.552 & 243 & 145 & 30 & 2.510 & 0.628 & $<0.0001^{* * *}$ \\
\hline P4 & 246 & 20 & 248 & 1.996 & 0.981 & 170 & 21 & 227 & 1.864 & 0.966 & $0.04 *$ \\
\hline P5 & 239 & 192 & 83 & 2.304 & 0.732 & 163 & 196 & 59 & 2.249 & 0.686 & 0.241 \\
\hline P6 & 404 & 78 & 32 & 2.724 & 0.570 & 322 & 64 & 32 & 2.694 & 0.605 & 0.4371 \\
\hline
\end{tabular}

\footnotetext{
$* \mathbf{p}<0.05, * * \mathbf{p}<0.01, * * * \mathbf{p}<0.001$
} 


\begin{tabular}{|c|c|c|c|c|c|c|c|c|c|c|c|}
\hline \multicolumn{6}{|c|}{ Age group 18-25: 574} & \multicolumn{5}{|c|}{ Age group 26-49: 349} & \multirow[b]{2}{*}{$p$ value } \\
\hline No. & $\mathbf{A}$ & B & $\mathbf{C}$ & Mean & SD & $\mathbf{A}$ & B & $\mathbf{C}$ & Mean & SD & \\
\hline K1 & 439 & 81 & 54 & 2.713 & 0.647 & 286 & 49 & 14 & 2.643 & 0.508 & 0.0851 \\
\hline $\mathbf{K} 2$ & 95 & 131 & 348 & 1.584 & 0.767 & 53 & 95 & 201 & 1.499 & 0.727 & 0.0963 \\
\hline K3 & 47 & 445 & 82 & 1.970 & 0.475 & 35 & 271 & 43 & 1.880 & 0.471 & $0.0052 * *$ \\
\hline K4 & 376 & 165 & 33 & 2.639 & 0.603 & 219 & 112 & 18 & 2.450 & 0.589 & $<0.0001 * * *$ \\
\hline K5 & 333 & 226 & 15 & 2.595 & 0.553 & 167 & 173 & 9 & 2.332 & 0.547 & $<0.0001 * * *$ \\
\hline A1 & 266 & 244 & 64 & 2.389 & 0.679 & 176 & 130 & 43 & 2.264 & 0.688 & $0.0071 * *$ \\
\hline A2 & 268 & 88 & 218 & 2.120 & 0.925 & 188 & 41 & 120 & 2.087 & 0.904 & 0.5962 \\
\hline A3 & 136 & 291 & 147 & 2.012 & 0.709 & 81 & 147 & 121 & 1.793 & 0.740 & $<0.0001 * * *$ \\
\hline P1 & 48 & 62 & 464 & 1.296 & 0.611 & 25 & 36 & 288 & 1.185 & 0.563 & $0.006^{* *}$ \\
\hline $\mathbf{P 2}$ & 66 & 178 & 330 & 1.565 & 0.698 & 58 & 139 & 152 & 1.646 & 0.715 & 0.0906 \\
\hline P3 & 368 & 169 & 37 & 2.618 & 0.618 & 253 & 79 & 17 & 2.545 & 0.564 & 0.0725 \\
\hline $\mathbf{P 4}$ & 258 & 24 & 292 & 1.972 & 0.986 & 150 & 16 & 183 & 1.812 & 0.954 & $0.0157 *$ \\
\hline P5 & 182 & 295 & 97 & 2.182 & 0.688 & 217 & 91 & 41 & 2.381 & 0.691 & $<0.0001 * * *$ \\
\hline P6 & 462 & 77 & 35 & 2.788 & 0.566 & 257 & 63 & 29 & 2.523 & 0.625 & $<0.0001 * * *$ \\
\hline
\end{tabular}

\footnotetext{
$* \mathbf{p}<0.05, * * \mathbf{p}<0.01, * * * \mathbf{p}<0.001$
} 